\title{
Aplikasi Konsep Luxury pada Interior Hotel Bisnis
}

\author{
Pricillia Devi Prahastuti dan Nanik Rachmaniyah \\ Departemen Desain Interior, Fakultas Teknik Sipil dan Perencanaan, Institut Teknologi Sepuluh Nopember (ITS) \\ e-mail: rachmaniyah@gmail.com
}

\begin{abstract}
Abstrak-Luxury sebagai salah satu gaya hidup yang saat ini digemari masyarakat sudah berkembang ke industri perhotelan. Hotel bisnis dengan tema luxury sebagai bagian dari industri perhotelan jumlahnya terus meningkat setiap tahun dikarenakan permintaan dan minat pasar yang ikut meningkat. Desain interior dengan tema luxury mempunyai ciri yaitu menggunakan bahan dengan kualitas yang baik dan dibuat dengan teknik yang baik pula, material logam dan reflektif, menggunakan produk dari desainer terkenal, dan memiliki nilai estetis yang lebih dari nilai fungsinya. Pengaplikasian dari konsep luxury ke dalam interior hotel meliputi beberapa bagian seperti plafon yang menggunakan up ceiling dan lampu gantung sebagai elemen estetis, dinding dengan partisi berupa pipa kayu yang disusun secara vertikal, furnitur dengan bentukan sederhana, pemakaian material dengan warna emas, dan penggunaan warna netral pada sebagian besar elemen interior yang ada pada hotel bisnis.
\end{abstract}

Kata Kunci-desain interior, hotel bisnis, luxury.

\section{PENDAHULUAN}

$\mathrm{D}$ ESAIN interior luxury adalah desain yang diaplikasikan pada hunian dan ruangan yang mewah dan properti komersial seperti hotel, restaurant yang memiliki target pasar masyarakat dengan ekonomi atas. Jenis desain interior ini berfokus pada penggunaan furnitur mahal, barang antik dan glamor, serta karya seni yang mewah.

Industri hotel luxury telah menjadi segmen umum yang signifikan dari industri perhotelan dan sedang mengalami ekspansi yang cepat. Pada bulan Februari 2013, Forbes Travel Guide Star Awards mengumumkan 76 hotel bintang lima dan 226 hotel bintang empat di seluruh dunia sebagai pemenang penghargaan, mengalami kenaikan tahunan masing-masing 33\% dan 28,4\%. Di September 2013, Forbes Travel Guide Star Awards memperbarui informasi bahwa jumlah hotel bintang lima dan hotel bintang empat meningkat menjadi 83 hotel bintang lima dan 264 hotel bintang empat, masingmasing meningkat $9 \%$ dan $16,8 \%$ hanya dalam enam bulan. Ini berarti setiap minggu satu hotel luxury baru dibangun di dunia selama periode ini [1].

Beberapa hotel bisnis di Indonesia juga menerapkan konsep luxury ke dalam interiornya karena meningkatnya minat masyarakat pada pasar luxury.

Aplikasi konsep luxury pada interior hotel bisnis meliputi berbagai aspek dari penggunaan furnitur, elemen estetis, dinding, lantai, warna, dan perncahayaan dengan menggunakan objek salah satu hotel bisnis di Indonesia.

Terdapat beberapa masalah yang akan menjadi topik utama penelitian ini, yaitu:

1. Apa hubungan antara minat masyarakat dalam mengunjungi hotel bisnis dengan konsep luxury pada interior?
2. Bagaimana pengaplikasian konsep luxury yang dapat diterapkan pada hotel bisnis?

Berdasarkan masalah di atas, maka dapat dirumuskan tujuan dari penelitian ini, yaitu:

1. Untuk mengetahui hubungan antara minat masyarakat dalam mengunjungi hotel bisnis dengan konsep luxury pada interior

2. Untuk mengetahui bagaimana pengaplikasian konsep luxury yang dapat diterapkan pada hotel bisnis.

\section{KAJIAN LITERATUR}

\section{A. Hotel Bisnis}

Kata 'Hotel' berasal dari bahasa latin yaitu 'hostel' dan berkembang menjadi 'Hotel' yang mulai dipakai pada abad 18 di London. Saat itu, kata hotel adalah 'garni' yang berarti sebuah rumah yang besar, dilengkapi dengan sarana tempat tinggal yang disewakan secara harian, mingguan, maupun bulanan.

Menurut SK Menparpostel Nomor. KM 34/HK 103/MPPT1987 pengertian dari hotel yaitu: "Hotel adalah suatu jenis akomodasi yang mempergunakan sebagian atau seluruh bangunan untuk menyediakan jasa pelayanan penginapan, makanan dan minuman, serta jasa lainnya untuk umum, yang dikelola secara komersial serta memenuhi persyaratan yang ditetapkan dalam keputusan pemerintah [2].

Menurut Time Saver Standart, ruangan dalam hotel dibagi menjadi dua, yaitu bagian depan (front of the house) dan bagian belakang (back of the house). Pengaturan fungsinya adalah sebagai berikut :

1. Back of the house : Fasilitas laundry, housekeeping department, servis makanan dan sayuran, dan ruang mekanikal.

2. Front of the house : Resepsionis, kasir, ruang administrasi, lobby, fasilitas transportasi vertikal mekanik (elevator), kamar tamu, kamar mandi tamu, restaurant, dan koridor [3].

Berdasarkan penelitian oleh Rahma Mastovani, 2014, hotel Bisnis adalah hotel yang mempunyai fasilitas yang dapat mengakomodasi seluruh kegiatan bisnis pengunjung. Hotel bisnis biasanya digunakan untuk pertemuan-pertemuan besar dan hotel untuk para tamu businessman [4].

Dalam menetukan lokasi hotel bisnis, akses dengan pusat kegiatan perdagangan dan jasa harus mudah dan cepat. Dari segi arsitekturnya, karakteristik dari hotel bisnis adalah merupakan bangunan tunggal dan dapat dibangun dilahan yang tidak terlalu luas, lebih mengeksplor dan memperhatikan bagian dalam bangunan, ruang-ruang didalam hotel harus memperhatikan sirkulasi antara zona publik seperti kelompok kegiatan umum, semi publik seperti kelompok kegiatan pengelola, service seperti kelompok kegiatan pelayanan, semi 
private yaitu kelompok tamu bersama dan private yaitu kegiatan menginap.

Sirkulasi setiap zona harus dieksplor dan dirancang agar mencapai kenyamanan pengguna hotel tersebut. Karakteristik lainnya yaitu fasilitas hiburan misalnya karaoke room dan fasilitas olahraga seperti kolam renang dan fitness centre hanya sebagai pelengkap yang disesuaikan dengan kelas bintang hotel yang direncanakan juga memperhatikan karakteristik dari pengguna hotel yaitu businessman.

\section{B. Luxury}

Definisi dari luxury dan hal yang berhubungan dengannya sering tidak jelas, tergantung dari perspektif masyarakat [5]. Barang luxury bisa didefinisikan sebagai semua hal yang masyarakat beli namun tidak dibutuhkan. Kebutuhan bukanlah alasan mengapa masyarakat membeli barang di pasar luxury. Konsumen barang luxury membeli atas dasar keinginan; mereka tidak membeli 'barang', namun perasaan yang menghasilkan pengalaman tertentu.

Luxury adalah tentang mencapai gaya hidup yang nyaman dan berpikir bahwa memiliki barang tertentu dapat membuat hidup terasa lebih baik, lebih menyenangkan dan memuaskan. Mempunyai gaya hidup luxury bukan tentang uang, namun tentang pengalaman dan perasaan 'memiliki uang'. Selain itu, masyarakat yang menerapkan gaya hidup ini akan mendapatkan status sosial yang tinggi, dikarenakan barangbarang luxury menandakan kekayaan seseorang dan selera yang bagus.

Pada jaman dahulu, ketika konsep luxury baru dikenalkan ke masyarakat, pengaruh tersebut berjalan dengan lambat ke masyarakat. Sekarang dengan adanya media, peran selebriti, majalah, dan televisi, hal tersebut memberikan pilihan baru ke masyarakat tentang produk yang bisa dibeli. Karena pengetahuan masyarakat tentang hal ini, konsumen luxury pun menginginkan untuk menjadi lebih glamor; bukan untuk memisahkan diri dari yang lain, namun untuk mengetahui rasanya menjadi bagian dari 'keglamoran' tersebut [6].

Hal yang membedakan barang biasa dengan barang luxury adalah barang biasa memiliki nilai fungsi yang lebih besar dibandingkan nilai estetisnya, sedangkan untuk barang luxury adalah sebaliknya.

Berbagai tempat yang menggunakan barang-barang luxury di dalamnya akan menarik minat masyarakat banyak; mereka datang untuk merasakan pengalaman ketika berada di lingkungan yang luxury.

Proses perancangan desain interior luxury tidak lebih mudah hanya karena desainer memiliki banyak pilihan aplikasi elemen interior. Pada desain interior jenis ini, ruangruang yang dimiliki umumnya cukup besar sehingga akan menjadi tantangan bagi desainer. Sebagai contoh dimana pada umumnya hunian memiliki dinding yang lebar, pada hunian luxury, dinding yang dimiliki adalah raksasa, sehingga tidak akan bagus jika dibiarkan kosong, namun juga tidak akan bagus jika hanya diberi karya seni yang kecil-kecil dan menumpuk.

Karakteristik dari desain interior luxury adalah :

- Penggunaan furnishing dengan material dan pengerjaan kualitas baik.

- Memiliki nilai estetis yang lebih dari nilai fungsinya.
- Penggunaan furnitur dan elemen interior yang mahal dan mewah, didesain oleh desainer terkenal, ataupun diproduksi oleh merk yang khusus untuk masyarakat high end.

- Penggunaan material logam mulia seperti emas dan silver.

- Elemen interior yang digunakan lebih sebagai pekerjaan seni, bukan untuk tujuan fungsional.
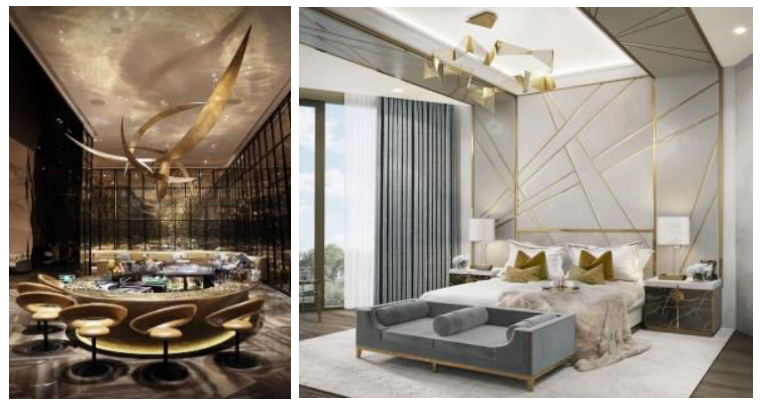

Gambar 1. Contoh interior luxury

Sumber : pinterest.com

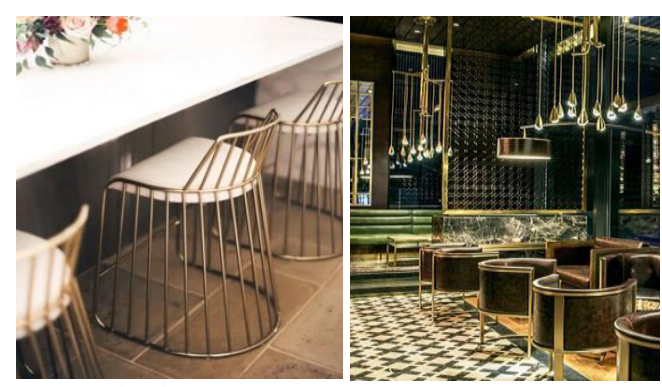

Gambar 2. Contoh furnitur luxury

Sumber : pinterest.com

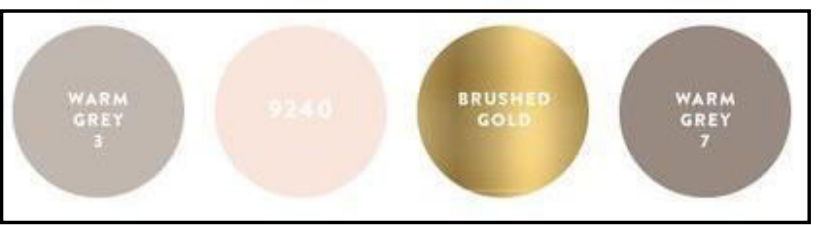

Gambar 3. Palet warna luxury

Sumber : pinterest.com

\section{URAIAN PENELITIAN}

\section{A. Proses Riset dan Teknik Pengumpulan Data}

Proses riset dan teknik pengumpulan data yang digunakan untuk menguraikan masalah dan mencari solusi permasalahan adalah sebagai berikut :

\section{1) Studi Literatur}

Studi literatur yang dilakukan melalui pencarian data dari jurnal, buku, laporan penelirian, dan lain-lain. Data yang didapatkan adalah tinjauan tentang hotel bisnis, gaya hidup luxury, desain interior luxury, dan desain interior hotel.

\section{2) Observasi}

Observasi yang dilakukan adalah meninjau lokasi hotel bisnis dan mengamati segala aktivitas pada ruang publik dan privat pada hotel bisnis tersebut. 


\section{3) Kuisioner}

Kuisioner yang dilakukan adalah untuk mencari data tentang kebutuhan pengguna hotel bisnis yang nantinya akan disesuaikan dengan konsep luxury yang digunakan.

\section{B. Hasil Observasi}

Berdasarkan observasi yang dilakukan, didapatkan kesimpulan sebagai berikut :

1. Fasilitas yang sangat sering digunakan di hotel bisnis adalah ruang pertemuan, restaurant, lounge, dan business centre.

2. Kualitas dari fasilitas penunjang seperti ruang pertemuan dalam hotel bisnis akan menentukan pengunjung yang menginap.

3. Ruangan publik dengan fasilitas lengkap dan desain interior yang fungsional menambah minat pengunjung untuk menggunakannya.

\section{Hasil Kuisioner}

Kuisioner dibagikan secara online dan diisi oleh 77 responden yang pernah mengunjungi hotel bisnis untuk keperluan perjalanan bisnis. Berikut adalah hasil kuisioner yang telah dibuat :

\section{1) Suasana yang lebih disukai pengunjung hotel}

Suasana yang indah dan mewah $(44,2 \%)$ merupakan pilihan yang paling banyak dipilih oleh responden, dengan pilihan lain berupa suasana yang santai dan nyaman seperti di rumah sendiri (39\%), dan suasana ruang yang sesuai dengan fungsi $(16,9 \%)$.

\section{2) Nilai pentingnya kenyamanan kamar}

Kenyamanan kamar merupakan hal yang sangat penting menurut responden $(59,2 \%)$, dengan pilihan lain berupa penting $(33,8 \%)$, dan biasa saja ( $7 \%)$.

3) Nilai pentingnya estetika interior

Estetika interior merupakan hal yang penting menurut responden $(57,7 \%)$, dengan pilihan lain sangat penting $(25,4 \%)$, biasa saja $(14,1 \%)$, dan tidak penting $(2,8 \%)$.

4) Nilai pentingnya teknologi canggih

Teknologi canggih merupakan hal yang sangat penting menurut responden (42,3\%), dengan pilihan lain berupa penting $(36,6 \%)$, biasa saja $(19,7 \%)$, dan tidak penting $(1,4 \%)$.

5) Nilai pentingnya fasilitas lengkap

Fasilitas lengkap merupakan hal yang sangat penting bagi responden $(52,1 \%)$, dengan pilihan lain berupa penting $(35,2 \%)$, biasa saja $(9,9 \%)$, dan tidak penting $(2,8 \%)$.

\section{6) Nilai pentingnya hiburan}

Hiburan merupakan hal yang penting bagi responden $(36,6 \%)$, dengan pilihan lain berupa biasa saja $(31 \%)$, sangat penting $(22,5 \%)$, dan tidak penting $(9,9 \%)$.

\section{APLIKASI KONSEP LUXURY}

Berdasarkan konsep luxury pada interior ruangan yang telah dijelaskan sebelumnya, dapat diaplikasikan ke berbagai elemen interior sebagai berikut :

\section{A. Aplikasi plafon}

Konsep plafon pada area publik menggunakan artwork atau lampu gantung yang akan menjadi titik fokus dari ruangan tersebut. Penggunaan kayu balok yang disusun secara paralel dan naik turun sehingga menunjukkan ketinggian yang berbeda.

Sedangkan pada area privat seperti kamar tamu dan area servis seperti kantor managemen hotel, bisa menggunakan down light biasa dengan plafon yang terbuat dari material kayu ataupun permainan plafon yang dibuat naik-turun dan menggunakan hidden lamp. Sebagai aksentuasi di tengah ruangan sebaiknya menggunakan chandelier dengan bentuk yang unik namun tetap sederhana.

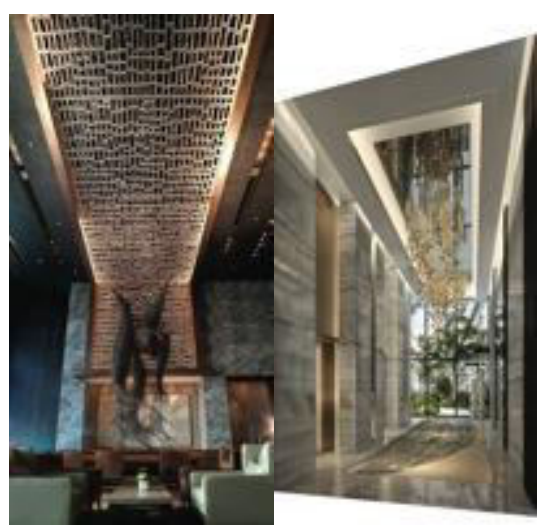

Gambar 4. Contoh aplikasi plafon.

Sumber : pinterest.com

\section{B. Aplikasi dinding}
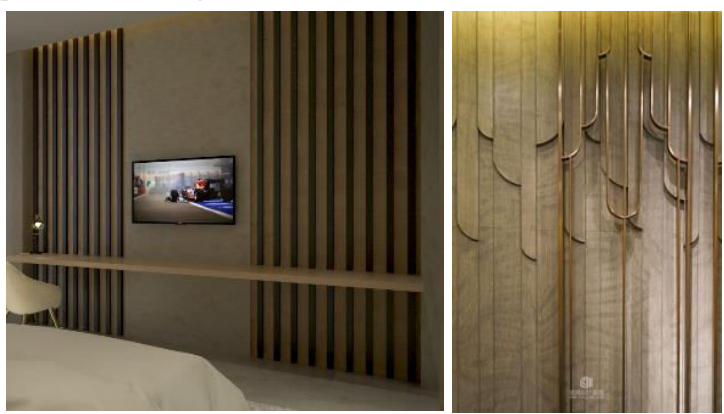

Gambar 5. Contoh aplikasi dinding

Sumber: Dokumentasi penulis (kiri), pinterest.com (kanan).

Dinding menggunakan material kayu-kayuan yang difinish natural sehingga seratnya terlihat dengan sedikit aplikasi metal atau permukaan yang glossy. Sedangkan di bagian tertentu menggunakan kaca atau permukaan yang glossy supaya ruangan terlihat lebih luas.

Penggunaan divider yang berbentuk pipa vertikal dengan ketebalan yang berbeda-beda juga bisa diaplikasikan untuk memberi kesan pemecah ruangan tanpa harus menutup semua pandangan ke arah lain.

Pada area service dan privat, penggunaan panel dari material kayu atau material gloss juga bisa diterapkan pada dinding. 


\section{Aplikasi lantai}

Desain lantai menggunakan material marmer dan granit dengan permukaan glossy sehingga menambah kesan mewah. Di bagian lain bisa menggunakan granit bermotif kayu.
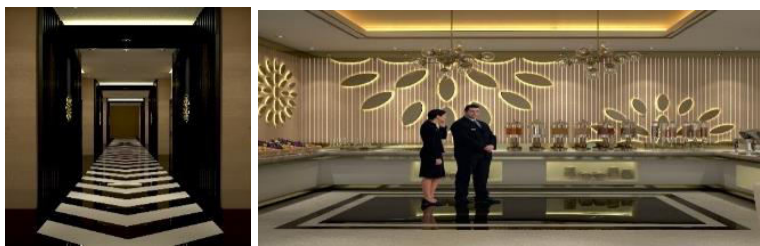

Gambar 6. Contoh aplikasi lantai

Sumber : Dokumentasi penulis

Penggunaan pola lantai juga sangat dianjurkan untuk membedakan area tertentu, dan supaya ruangan tidak terlihat monoton.

Sedangkan untuk area yang menyediakan area duduk berkelompok seperti lounge, menggunakan karpet dengan motif sederhana yang ukurannya hanya seluas area kelompok tersebut.

\section{Aplikasi furnitur}

Furnitur yang digunakan adalah yang mempunyai bentuk geometris dan lengkungan dengan sudut yang lebar, tidak bulky, dan menggunakan warna netral dengan frame metal atau kayu yang mempunyai diameter kecil.
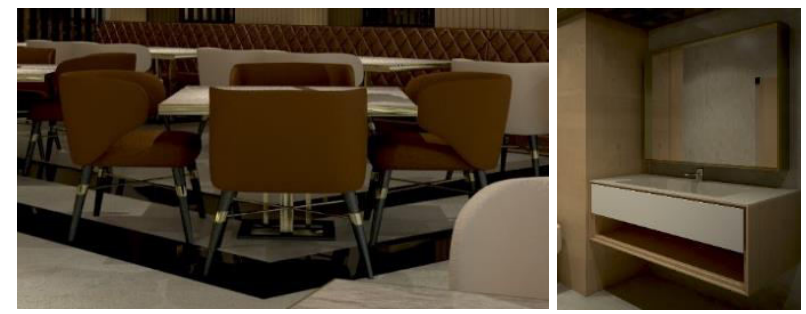

Gambar 7. Contoh aplikasi furnitur

Sumber : Dokumentasi penulis

Penggunaan finishing dengan warna emas dan material logam juga dapat menambah kesan luxury pada ruangan.

\section{E. Aplikasi elemen estetis}

Elemen estetis yang digunakan berupa artwork yang digantung, dijadikan chandelier, patung, maupun lukisan yang dipasang di dinding. Dikarenakan ruangan yang didesain adalah ruangan dengan skala besar, maka ukuran artwork diharuskan besar juga namun tidak boleh terkesan raksasa dan menghabiskan banyak tempat.
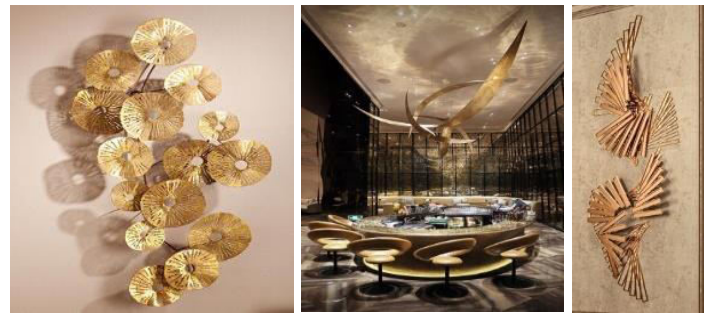

Gambar 8. Contoh aplikasi elemen estetis
Sumber : pinterest.com

\section{F. Aplikasi warna}

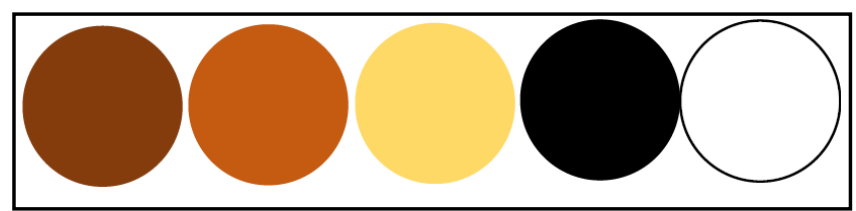

Gambar 9. Contoh aplikasi warna

Sumber : Dokumentasi penulis

Warna yang digunakan antara lain adalah warna alami seperti warna kayu yaitu coklat dan turunannya, warna kuning keemasan, warna hitam, dan warna putih.

\section{G. Aplikasi pencahayaan}

Aplikasi pencahayaan pada interior hotel bisnis yang digunakan adalah pencahayaan tidak langsung seperti hidden lamp yang dipasang di plafon maupun di lantai.


Gambar 10. Contoh aplikasi pencahayaan Sumber : Dokumentasi penulis

\section{PENUTUP}

\section{A. Kesimpulan}

Kesimpulan keseluruhan yang dapat diambil ada beberapa poin yaitu :

1. Menggunakan konsep luxury pada interior hotel bisnis akan meningkatkan minat masyarakat untuk mengunjungi hotel bisnis tersebut karena masyarakat cenderung menyukai barang dan suasana luxury.

2. Konsep luxury pada interior hotel bisnis dapat diterapkan dengan menggunakan artwork dan lampu gantung pada plafon, menggunakan panel yang terbuat dari kayu dan divider yang terbuat dari logam pada dinding, menggunakan marmer dan parquet pada lantai, menggunakan bentukan sederhana untuk furnitur dan elemen estetis, menggunakan warna netral, dan menggunakan pencahayaan tidak langsung dengan warna yang hangat.

\section{B. Saran}

Saran yang dapat diberikan dari penelitian ini adalah memperbanyak kajian tentang perilaku pengunjung hotel bisnis dengan konsep luxury dengan variable yang berbeda sehingga ada banyak referensi ketika meneliti objek hotel bisnis. 


\section{DAFTAR PUSTAKA}

[1] V. de Barnier, "Which Luxury Perceptions Affect Most Consumer Purchase Behavior? A Cross Cultural Exploratory Study in France, The United Kingdom, and Russia."

[2] E. Marlina, Panduan Perancangan Bangunan Komersial, 1st ed. Yogyakarta: ANDI OFFSET, 2008.
[3] M. Zelnik, "Time Saver Standarts for Interior Design and Space Planning," 1991.

[4] R. Mastovani, "Hotel Bisnis Bintang 4 di Jambi," 2011.

[5] K. Heine, Concept of Luxury Brands. Berlin, 2011.

[6] A. Joy, "M(Art)Worlds: Consumer Perceptions of How Luxury Brand Stores Become Art Institutions," 2014. 